\title{
The Effect of Islamic Work Ethics on Affective Commitment of Vocational High School Teachers
}

\author{
Umi Anugerah Izzati \\ Department of Psychology, Faculty of Education \\ Universitas Negeri Surabaya \\ Surabaya, Indonesia \\ umianugerah@unesa.ac.id
}

\begin{abstract}
In some vocational schools, teachers demonstrate lack of affective commitment to the schools. They mostly haven't shown maximum effort to exert their potentials related to the values of good and bad behavior in the work. The objective of this study is to investigate the impact of Islamic work ethics on the affective commitment. This study used quantitative approach and involved the total population of 108 teachers working at vocational high schools. In this study, data collection technique used questionnaires which comprised namely Islamic work ethics and affective commitment. Data analysis technique used linear regression. The result suggests that Islamic work ethics have a positive influence on affective commitment. The higher Islamic work ethics that the teachers own, the more they are bound emotionally to, able to identify, and engaged with the vocational schools where they work.
\end{abstract}

Keywords-Islamic work ethics, affective commitment, teachers.

\section{INTRODUCTION}

Good quality education can be achieved if the schools have teachers with high levels of commitment. Park [1] advanced the reasons why teacher commitment should be emphasized in the fields of education. One reason is the commitment is an internal force that comes from within the teachers themselves. Internally, teachers have a variety of responsibilities and challenges in their work as their level of participation in education. Participation in education show teachers' commitment on the school organization where they worked.

[2] Proposed that organizational commitment can be defined as a psychological state that shows the relationship of employees with the organization and a willingness to maintain membership in the organization. Organizational commitment has three components: affective commitment, continuance commitment, and normative commitment. Affective commitment is the employees' emotional attachment to, identification as part of, and involvement with the organization due to some values in the organization to promote it. Affective commitment develops based on the psychological aspects as it involves the affective side which is a feeling of attachment possessed by the individuals to an organization where they work. Continuance commitment is the extent to which a person has the intention to keep working on the organization based on the cost-benefit consideration if the employee leaves the organization. This commitment is formed by the economic considerations of the employee to the organization. Meanwhile, normative commitment is the extent to which a worker feels an obligation to continue working in the organization. Normative commitment is related to the social experiences of the individual in accordance with the norm.

Selection of affective commitment as the focus of this study is based on some previous research showing that affective commitment has a significant role compared to two other commitments, including [3] which shows that affective commitment has a higher influence compared with normative and continuance commitment. The results of [4] research stated that affective commitment correlated with a variety of organizational behavior and employee performance such as presence, late-coming, slow work, employee turnover, as well as poor labor productivity. It is also described in a research by [5] who argued that the low level of affective commitment has impacted on employees' performance in work, turnover, and levels of absenteeism. Therefore, lack of affective commitment may affect the achievement of organizational goals.

Many research had suggested that affective commitment has an important role for the survival and the achievement of organizational goals. Meanwhile, based on observations and interviews at two private Vocational High Schools run by Islamic educational institutions, it was found out that there were eight teachers who were absent in the classroom during the teaching hours, six teachers came late to class more than 30 minutes, the teachers of multimedia subject often changed every semester since the previous teachers moved to other schools, and some teachers who had been given the assignment in school accreditation activities did not want to get involved. Referring to the affective commitment indicators proposed by [6], these facts show lack of teachers' affective commitment working at the vocational high school.

Some research claimed that Islamic work ethics influence affective organizational commitment, including [7], who examined the relationship between Islamic work ethics, organizational commitment, and job satisfaction. This research was conducted in the United Arab Emirates with a sample of 425 employees working in various companies. The results show that the Islamic work ethics directly influence the organizational commitment and satisfaction of subordinates, 
and it mediates the relationship between organizational commitment and job satisfaction.

Research on Islamic work ethics has also been carried out in Malaysia. [8] examined the relationship between Islamic work ethics and organizational commitment. In the study, he used three dimensions of organizational commitment that is affective, normative and continuance commitment. The sample consisted of 227 employees working at various banks in Malaysia. The results show that Islamic work ethics have a positive influence on the three dimensions in organizational commitment. It is further disclosed that affective commitment have a greater influence than normative and continuance commitment.

Another study was also conducted by [9], who examined the relationship between Islamic work ethics and organizational commitment in the banking industry using three dimensions of commitment, namely affective, continuance and normative commitment. The study found that there was a significant positive relationship between Islamic work ethic and all dimensions of organizational commitment. This study also resulted in the finding that affective commitment has a higher correlation compared to other commitments. [10] in a study of academic employees in Malaysia has resulted in findings that Islamic work ethics affect organizational commitment. A study by [11] also suggested that the work ethic of Islam has a positive relationship with organizational commitment.

[12] studied investigating the relationship between islamic work ethics and organizational commitment at police employees. In the study, they used three components of organizational commitment that is affective, normative and continuance commitment. The sample consisted of 220 employees from Gilan Province Police. The results show that there is positive meaningful relationship between Islamic work ethics and the three components in organizational commitment

Meanwhile, [13] also studied the influence of Islamic work ethics to organizational commitment on employees working in textiles industries located in Selangor, Kuala Lumpur and Johor. The results show that the Islamic work ethics affect all dimensions of organizational commitment and the greatest contributor of the influence is affective commitment.

Working in Islam is a dedicative efforts in striving to increase self-interest economically, socially and psychologically, in order to sustain social prestige, to promote social welfare and reaffirm faith. It could also be said that the purpose of work is to maintain five human needs, which comprise their faith, self, intelligence, descendants and wealth. Therefore, it is important for people to pursue whatever job is available, whenever it is available, subject to the will of God [14].

[15] contended that Islamic work ethics are behaviors in the workplace that include effort, responsibility, social and creativity. Islamic work ethic is an orientation that shapes and influences the engagement and participation of workers, which can be viewed from the effort, competition, transparency, and responsibility which is based on Islamic values [16]. Meanwhile, according to [2] Islamic work ethics can be defined as a set of moral principles that distinguish right and wrong in the context of Islamic values [13]. defines Islamic work ethics is an orientation that shapes and influences the involvement and participation of Muslims in the workplace. The work ethic of Islam see work as a way to view the societal benefit rather than personal interests as well as economic, social, and psychological as well as improve social welfare and strengthens faith.

So far, the research on Islamic work ethics and organizational affective commitment is more related to the field of industry, police department and banking. To the researcher's knowledge, study on Islamic work ethics and affective organizational commitment of the vocational secondary school teachers in Islamic educational institutions does not exist. Research on the ethics of Islamic work is interesting to be studied in vocational high schools. This is because the vocational high schools that are in Islamic educational institutions have Islamic values that are part of the ethics of Islamic work.

The Islamic values that are the foundation in the educational institution at this place of study consist of ikhlas, trust, ukhuwah, discipline, hard work, work thoroughly and give benefit. Ikhlas is giving service to others wholeheartedly without expecting reward. trust is to keep the trust that has been given. Ukhuwah means to foster interpersonal relationships and establish cooperation with everyone. Discipline is to comply with rules and work procedures that have been established in the school environment. Working hard means being earnest in doing the job. Working thoroughly is able to complete the job thoroughly. While giving the benefits in question is all things done can provide benefits for everyone, especially for everyone who is in the school environment. The values that exist in Islamic educational institutions are guidelines that must be implemented by all those who work in it with full sense of responsibility.

Therefore, the researcher is interested in conducting a study related to Islamic work ethic and affective organizational commitment on teachers of vocational schools who work in one Islamic educational institution in Surabaya.

This study sought to answer the following research question: Is there any influence of Islamic Work Ethics on Affective Organizational Commitment of Vocational Secondary School Teachers?

\section{METHODS}

This research was conducted using quantitative research methods. The study design is a field study. Criteria of samples taken in this study is teachers working at vocational schools of one Islamic education institution have a minimum education 
of undergraduate level. In this study, the researcher used a total population of two vocational secondary schools so that the number of respondents of this study is 108 people.

The instrument used in this study is the scale of Islamic Work Ethics developed by the researcher based on concept [17]. The reliabilities of ranged between 0.677 and 0.822 . Cronbach's Alpha consistency of 0.949. This study also used the affective commitment scale developed by the researcher based on the concept of [18]. The reliabilities of the affective commitment ranged between 0.641 and 0.810. The Cronbach's alpha for affective commitment is 0.943. Each statement in the both of instruments provided six points Likerts scale with one indicating strongly disagree and six indicating strongly agree. The data collected were analyzed using linear regression to determine whether there is influence of Islamic work ethics on affective commitment of teachers.

\section{RESULT AND DISCUSSION}

The number of participants is 108 and categorized into male participants of 46 and female of 62 teachers. The data in this study was analyzed using linear regression analysis and descriptive analysis.

Based on the results of the descriptive analysis of data, respondents who have Islamic work ethics in the high category of $55.6 \%$ (60 teachers), medium category of $38.9 \%$ (42 teachers) and low category is 5.6\% (6 teachers). Meanwhile affective commitment was in the high category category of $57.46 \%$ (62 teachers), the moderate category was $39.8 \%$ (43 teachers) and the low category was $2.8 \%$ (3 teachers). This shows that most teachers have Islamic work ethics. Beside that teachers have a high affective commitment.

TABLE I. REGRESSION ANALYSIS COEFFICIENTS

\begin{tabular}{cccc}
\hline Model & $\beta$ & $\mathrm{t}$ & \multicolumn{2}{c}{ Sig. } \\
& & & \\
\hline Islamic Work Ethics & 0.786 & 0.43 & 0.000 \\
& & & \\
$\mathrm{R}^{2}$ & & 0.761 & \\
$\mathrm{~F}$ & & 337.361 & \\
Significance & & 0.000 &
\end{tabular}

Based on the regression linier described above, Islamic Work Ethics $\mathrm{R}^{2}$ has contributed as much as 0.761 so that it can be said that the Islamic Work Ethics has a considerable influence on the affective commitment. The beta value of 0.786 (positive) with a significance value of 0.000 is smaller than the significance level used $(\alpha=0.05)$. This show that coefficients determinat value of 0.761 . It means this value show that $76.1 \%$ data variance affective commitment can explain by Islamic work ethic and have influence $76.1 \%$ to affective commitment. Beside that the result of $F$ shows significance 0.000 it means that model influence Islamic Work Ethics to affective commitment can use. While $23.9 \%$ determined other factors including personal characteristics, organizational character and work experience.

The result of this study indicated that Islamic work ethics have a strong influence on affective commitment. The value of the influence of Islamic work ethics on organizational affective commitment is because this research is conducted in two vocational high schools that are in the environment of Islamic educational institutions that apply the values of the organization based on the teachings of Islam. Beside that, working in Islam is a dedicative efforts in striving to increase self-interest economically, socially and psychologically, in order to sustain social prestige, to promote social welfare and reaffirm faith [14].

Teachers who apply islamic work ethics in the work have a strong attachment to the school organization where they work. Islamic work ethics according to [16] is a set of moral principles that distinguish right and wrong in the context of Islamic values. As expressed by [19] work must provide benefits and means. That is, in the work must be beneficial to others and society in general while serving as a source of pride and a life of dignity and balance. Basically the main concepts of Islamic work ethics are business, competition, transparency and morally responsible behavior. Business is seen as a need to serve oneself and society. In Islam doing business is the most important thing.

High Islamic work ethics emphasizes the effort to work hard by paying attention to deadlines, goals and persistence to get things done. In the islamic work ethic, work is also seen as a means to encourage personal growth and social relationships. In this case group interaction and team activities can be established good cooperation. Dedication to work is seen as a virtue to provide service to others.

In vocational high school teachers within the scope of Islamic education institutions have applied organizational values consisting of ikhlas, trust, ukhuwah, discipline, work hard, work thoroughly and provide benefits. The values are part of the ethics of Islamic work. Ikhlas is that teachers have provided service to others wholeheartedly including colleagues, bosses and students. Trust indicates that teachers have been able to keep the trust that has been given. Ukhuwah means the teachers have done a good cooperation so that the execution of the task can be well executed. In the work, teachers have demonstrated discipline so as to comply with the rules and work procedures that have been established in the school environment. In addition, teachers are also serious in carrying out the work and can complete the tasks that are the responsibility. While giving the benefits in question is all things done can provide benefits for everyone, especially for everyone who is in the school environment.

It also shows that vocational high school teachers working in Islamic educational institutions have a high ethical work ethic in performing their duties. Teachers shows as [16] islamic work ethic as deligent, dedication to work benefits both one's self and others, good work benefits both one's self and others, justice and generosity in the workplace are 
necessary conditions for society's welfare, producing more than enough to meet one's personal needs contributes to the prosperity of society as a whole, work out to the best of one's ability, foster personal growth and social relations, life has meaning when work, society necessary, human relations in organizations should be emphasized and encouraged, work enables mankind to control nature, creative work is a source of happiness and accomplishment, person who works is more likely to get ahead in life, work gives one the chance to be independent, solve deadlines at work, constantly work hard to meet responsibilities, the value of work is derived from the accompanying intention rather than its results. Teachers who have a high ethical work of Islam can shape and influence involvement and participation in work [19]. Involvement and participation in performing work indicate the desire of teachers to be emotionally attached to the vocational high school in which they work.

The results of this study indicate that the higher the work ethic of Islam is, the higher the affective commitment has emerged among teachers. Likewise, the lower the work ethic of Islam owned by teachers, the lower the affective commitment has appeared. These findings support several previous studies that have been done including [7], who examined the relationship between Islamic work ethics, organizational commitment, and job satisfaction. The results show that the Islamic work ethics directly influence the organizational commitment and satisfaction of subordinates, and it mediates the relationship between organizational commitment and job satisfaction.[8] have a reseach sample consisted of employees working at various banks in Malaysia. The results show that Islamic work ethics have a positive influence on affective commitment.

[9], who examined the relationship between Islamic work ethics and organizational commitment in the banking industry. This study resulted in the finding that affective commitment has a higher correlation compared to other commitments. [10] in a study of academic employees in Malaysia has resulted in findings that Islamic work ethics affect organizational commitment. A study by [11] also suggested that the work ethic of Islam has a positive relationship with organizational commitment.

The result of this research also support [12] studied investigating the relationship between islamic work ethics and organizational commitment at police employees. The results show that there is positive meaningful relationship between Islamic work ethics and the three components in organizational commitment. Meanwhile, [13] also result that studied the influence of Islamic work ethics have influence to affective organizational commitment on employees working in textiles industries located in Selangor, Kuala Lumpur and Johor.

Affective commitment can be established if members of a school organization have a desire to engage in the running of organizational values and strive to realize organizational goals as first priority. Affective commitment lies in the shared values, both among members of the organization, as well as between members of the organization and its organization. The rules of right and wrong and the value that is considered wrong in one of these groups is called ethics. Thus, the ethics of Islamic work becomes one of the important factors in realizing affective commitment of members of the organization.

Teachers who have high Islamic work ethics would work by exerting their maximum efforts and demonstrate dedication to advance the social welfare and reaffirm the faith. It also shows that these teachers will feel emotionally attached to the school organization where they worked. Individuals who have a strong affective commitment will identify, engage and enjoy their membership in the organization.

\section{CONCLUSION}

This study concluded that Islamic work ethics has an influence on the affective commitment of teachers of Vocational High School. Teachers who have high Islamic work ethics will demonstrate high affective commitment to the vocational school.

This study has limitations that only a limited number of subjects recruited from one of Islamic educational institutions in Surabaya. Furthermore, the number of secondary schools in Surabaya consists of many public and private vocational high schools. In addition, this study put less attention to other variables that can influence the affective organizational commitment.

\section{REFERENCES}

[1] Saha, L. \& Dworkin, A. Introduction New Perspective On Teacher and Teaching, International Handbook of Research on Teacher and Teaching. Part one. Springer. New York, 3-11, 2009.

[2] Meyer, J. P. \& Natalie J. A. Commitment in the Work Place, Theory, Research and Application. Sage Publication, 1997.

[3] Meyer, J. P., Stanley, D. J., Lynne, H., \& Laryssa, T. Affective, Countinuance, and Normative Commitment to the Organization: A Meta-analysis of Antecedents, Correlates, and Consequences. Journal of Vocational Behavioral 61, 20-52, 2002.

[4] Boezeman, E. J., \& Ellemers, N. Pride and respects in volunteers organizational commitment. European Journal of Social Psychology, 38(1), 159-172. 2008.

[5] Aamir, S., \& Ayesha, K. Impact of employee empowerment on employee's job satisfaction and commitment with the organization. Interdiciplinary Journal of Contemporary Research In Business, 3(2), 664-683. 2011

[6] Allen, N.J., \& Meyer, J.P. The measurement and antecedents of Affective, Continueance and Normative commitments to the organization", Journal of occupational psychology, vol.63, pp: 1-18, 1990.

[7] Yousef, D. A. Organizational commitment as a mediator of the relationship between Islamic Work Ethics and attitudes toward organizational change. Human Relations, 53 (4), 513-537, 2000.

[8] Rahman, N.M, Muhammad,N \& Othman, A.S. The relationship beween Islamic work ethics and oganizational commitment : A case analysis. Malaysian Management Review, 41 (1), 79-89, 2006.

[9] Mutasim, N.A.R., Nordin, M, Abdullah, S.O. The relationship between Islamic work Ethics and organizational commitment : A case analysiss Malaysian Management Review, 41(1) : 79-89, 2006. 
[10] Usman, M., Shahzad., Khan., K. Islamic Work Ethics (IWE) : A Review of Literature and Directions for Future Research. Journal of Islamic Business and Management Vo. 5 No. 2, 2015.

[11] Hayati.,K \& Caniago, I. Islamic Work Ethic : The role of intrinsic motivation, job satisfaction, organizational commitment and job performance. Procedia-Social and Behavioral Sciences, 65,272-177, 2012.

[12] Farsi, J.H.,Shiraz.,R.P.,Rodgarneshad, F. Anbardan, Y. Investigating the Relationship between Islamic work ethics and Organizational Commitment and Its Components A case stusy of Gilan Provience Police Employees. Journal UMP Scial Science and Technology Management Vo. 3, Issue 2, 2015.

[13] Salahudin, et. al. The Effect Of Islamic Work Ethic On Organizational Commitment. Procedia Economics and Finance 35, pp. 582-590, 2016.

[14] Khadijah, A.S, Kamaluddin, N., \& Salin, A.S.A.P. Islamic Work Ethics (IWE) Practice among Employees of Banking Sectors. Middle-East Journal of Scientific Research, 23 (5), 924-931, 2015

[15] Salem, Agil. Relationship between Islamic management ethic and commitment. Journal of Economics and Behavioral Studies. Vol. 4, 2012.

[16] Ali, J.A. Scaling an Islamic work ethic. Journal of Social Psychology. Vol. 128 No. 5, 2001.

[17] Ali, A.J., \& Kazemi, A.A., Islamic Work Ethic in Kuwait. Cross Cultural Management : An International Journal, Vol. 14, No. 2. pp. 93104, 2007.

[18] Meyer, J. P., \& Allen, N. J. A three-component conceptualization of organizational commitment. Human Resource Management Review, 1(1), 64-98, 1991.

[19] Ali, A.J., \& Owaihan, A., Islamic Work Ethic a Critical Review. Cross Cultural Management : An International Journal, Vol. 15, No. 1. pp. 519. 2008. 